\title{
シリコンフォトニクスの現状と将来
}

\author{
木村忠正 \\ 電気通信大学 電子工学科 (₹182-8585 東京都調布市調布ヶ 丘1-5-1)
}

\section{Preface to Special Issue on Frontiers of Silicon Photonics - Present Status and Future}

\author{
Tadamasa KIMURA \\ Department of Electronic Engineering, University of Electro-Communications, 1-5-1 Chofugaoka, Chofu, Tokyo 182-8585
}

(Received April 3, 2007)

Key Words: LSI-scaling, Optical interconnection, Silicon photonics, CMOS compatible, Silicon optical devices

LSIの縮小化が1974年のMooreの法則の提唱以来，およ そ一世代 (3年)毎に×0.7のスピードで進んできた. ITRS (Inernational Technology Roadmap for Semiconductors) 20051) では，この縮小化の努力は今後もしばらく続き，高性能 ロジックテクノロジーでは第1層のメタル配線のハーフ ピッチの值は2010年に $45 \mathrm{~nm}$ を切ると予測している。 しか し，スケーリングが技術的にもコスト的にもますます難 しくなることは明らかである。デバイス性能面では, 短 チャネル効果, 電流リーク, 発熱, 配線構造の複雑化, 信号遅延などの課題がある.なかでも, 配線の多層化, 複雑化，および，配線幅の縮小と配線長の増大による信 号遅延は解決すべき重要な問題である．IBMが1997年に導 入した $\mathrm{Cu}$ 配線も，配線幅の縮小化で粒界散乱，界面散乱 により抵抗率が増加し，32 nmノードではAl配線の抵抗率 を超え，何らかの対策が求められている. クロックの高 速化に伴う信号劣化や消費電力増大，電磁干渉などの問 題も深刻化し，15２0 Gbps程度で頭打ちになると予測さ れるなど，その限界が見えつつある。

金属配線の限界解決のために期待されているのがチッ プ内光配線である，光による信号伝達は，高周波におい ても信号損失が少なく，クロストークもほとんど発生し ないなど，広帯域の通信をサポートできるという利点が ある.この光配線をシリコンチップ内に光導波路として 関連するフォトニックデバイスとともに導入し，信号遅 延, 複雑多層配線の問題を解決する動きが始まってお り, LSIの中に組み込み可能な種々のシリコン光デバイス や光回路に関する研究が報告されている.ただし，この ような新しい光デバイスを既存の高度に成熟したシリコ ンLSIと共に集積化して使うためには，作製プロセスが材 料も含めてシリコンCMOS プロセスに適合すること, サ イズが十分に小さいこと, 性能やコスト面で光デバイス を導入するメリットが大きいことが要求される.
シリコンフォトニクスが現実のものとして注目されるよ うになった契機の一つに，シリコン光導波路の開発があげ られる. LSIの微細化やMEMSの進歩に伴うナノメータ精 度のシリコン微細加工技術の進歩により, 光通信波長带 (1.3-1.6 $\mu \mathrm{m})$ において $1 \mathrm{~dB} / \mathrm{cm}$ 以下の低い伝送損失, マイク ロメータオーダの曲げ半径が可能なサブミクロン幅のシリ コン光導波路が，フォトニクス結晶やシリコン細線を用い て作製可能となった ${ }^{2)}$. 基本的で重要な光導波路が可能に なったのを受け, シリコンを用いた共振器, 方向性結合 器, 分岐結合, 合分波, AWG (Arrayed Waveguide Grating), $10 \mathrm{Gbps}$ を超える高速光変調や光スイッチなどが次々と発 表された. シリコンの半導体的性質が利用でき, 電気的制 御が可能であることも大きな特徵である.ここに，単なる 光配線ではなく, LSIの電気信号処理と光信号処理を混載 あるいは融合した技術としてのシリコンフォトニクスの可 能性が生じた。

遅いと思われたプラズマ分散効果 (自由キャリヤによる 屈折率変化)による光変調, スイッチも, マイクロリング (デイスク) 共振器あるいはMach-Zehnder共振器と逆バイア スpin構造とを組合わせることで高速化が可能であること が示され, 現時点で $20 \mathrm{GHz}, 30 \mathrm{Gbps}$ という值が報告され ている3)。また，単結晶シリコンには無い大きな非線形光 学係数 $\left(\chi^{(2)} \sim 15 \mathrm{pm} / \mathrm{V}\right)$ をひずみシリコンが示すことが報告 され4), さらなる高速変調，スイッチが期待される．微細 化した光導波路の大きな群屈折率の発見は, 光デバイスの 課題であった光メモリー機能実現の可能性を示す5). 光 ファイバとシリコン細線などの光導波路との結合技術, ア センブリー技術などの周辺技術の開発も急速に進んでい る.

このように，シリコンフォトニクスへの期待は大きい が，LSIの立場からはフォトニクスデバイスの個々のサイ ズがまだまだ大きい点, 個々の光デバイスの機能により構 
造やプロセスが様々である点が課題である。そのような 理由から，先ずは，高速，大容量，配線の簡易化，低コ スト化が見込まれるボード間，チップ間に光インターコ ネクションと関連デバイスが導入されるであろう。実 際，CMOSフォトニクス技術で作製した $10 \mathrm{Gbps}$ 超える XFP 型 (10 Gigabit small Form-factor Pluggable) 光トランシー バがLuxteraから発表されているお。東大の和田一実教授 の提唱している，単一構造光デバイスの回路構成で種々 の光機能を実現するという方向は，LSIにおける CMOSFETの回路構成の工夫で種々の機能を実現するとい う考え方を取り入れたもので，シリコンフォトニクスが 実際にLSIに組み込まれるために考慮すべき重要な点であ る。最終的に残された課題は，シリコンフォトニクス用 の光源, 光増幅器である. 当面は, III-V化合物半導体 LD を外部からあるいはSiチップ上に組み达むことで進むと思 われるが，Erを含むシリコン系材料，シリコンナノクリ
スタル，局所ひずみ導入シリコンに扔ける直接遷移の可 能性などの研究が進んでおり，高効率Si-LEDはもとよ り, 電気励起光増幅器, LDの実現も夢ではない.

\section{参考文献}

1) ITRS INTERNATIONAL TECHNOLOGY ROADMAP FOR SEMICONDUCTORS 2005 EDITION

2) K. K. Lee, D. R. Lim, L. C. Kimerling, J. Shin, and F. Cerrina: Opt. Lett. 26 (2001) 1888.

3) A. Liu, R. Jones, L. Liao, D. Samara-Rubio, D. Rubin, O. Cohen, R. Nicolaescu, and M. Paniccia: Nature 427 (2004) 615.

4) R. S. Jacobsen, K. N. Andersen, P. I. Borel, J. Fage-Pedersen, L. H. Frandsen, O. Hansen, M. Kristensen, A. V. Lavrinenko, G. Moulin, H. Ou, C. Peucheret, B. Zsigri, and A. Bjarklev: Nature 441 (2006) 199.

5) M. Notomi, K. Yamada, A. Shinya, J. Takahashi, C. Takahashi, and I. Yokohama: Phys. Rev. Lett. 87 (2001) 253902.

† URL: http://www.luxtera.com/news_press_2006_0822.htm 